\title{
Plant communities and landscapes of the Parque Nacional do Limpopo, Moçambique
}

\section{Stalmans, W.P.D Gertenbach and Filipa Carvalho-Serfontein}

Stalmans, M., W.P.D Gertenbach and Filipa Carvalho-Serfontein. 2004. Plant communities and landscapes of the Parque Nacional do Limpopo, Moçambique. Koedoe 47(2): 61-81. Pretoria. ISSN 0075-6458.

The Parque Nacional do Limpopo (Limpopo National Park) was proclaimed during 2002. It covers 1000000 ha in Mocambique on the eastern boundary of the Kruger National Park and forms one of the major components of the Great Limpopo Transfrontier Park. A vegetation map was required as input to its management plan. The major objectives of the study were firstly to understand the environmental determinants of the vegetation, secondly to identify individual plant communities and thirdly to delineate landscapes in terms of their plant community make-up, environmental determinants and distribution. A combination of fieldwork and analysis of LANDSAT satellite imagery was used. A total of 175 sample plots were surveyed. Information from another 363 sites that were briefly assessed during aerial and ground surveys was used to further define the extent of the landscapes. The ordination results indicate the overriding importance of moisture availability in determining vegetation composition. Fifteen distinct plant communities are recognised. Different combinations of these plant communities are grouped into ten landscapes. These strongly reflect the underlying geology. The landscapes of the park have strong affinities to a number of landscapes found in the adjoining Kruger National Park. The main difference is the much greater importance of sandveld landscapes in Parque Nacional do Limpopo. Sandveld constitutes $44 \%$ of its surface area. This represents an area 30 times larger than the total extent of sandveld found in Kruger National Park. This has important implications in that the Parque Nacional do Limpopo contributes in its own right to the conservation value of the transfrontier park. Individual and joint management strategies for Parque Nacional do Limpopo and Kruger National Park need to take into account the different proportional make-up of both areas in terms of their landscapes. The landscape approach has resulted in a common characterization of the two parks that can be used for conservation evaluation, management and planning within the transfrontier context.

O Parque Nacional do Limpopo foi proclamado em 2002 e cobre uma área de 1000000 ha.
Situa-se em Moçambique, na fronteira leste do Parque Nacional do Kruger, e constitui um
dos maiores componentes do Grande Parque Transfronteiriço do Limpopo. Um mapa da
vegetação era necessário para integrar no Plano de Maneio. Os principais objectivos deste
estudo foram: primeiro, entender os factores ambientais determinantes da vegetação; segun-
do, identificar as comunidades vegetais individuais; e terceiro, delinear as paisagens em ter-
mos das suas comunidades vegetais representantes, factores ambientais determinantes e dis-
tribuição.
O método utilizado consistiu em combinar trabalho de campo com a análise de imagens
satélite LANDSAT. No total, fizeram-se levantamentos em 175 unidades de amostragem.
Informação adicional de 365 locais, resultante de breves reconhecimentos aéreos e ter-
restres, foi também utilizada para apoiar a delimitar as paisagens.
Os resultados indicam a importância capital que a disponibilidade de água tem na determi-
nação da composição vegetal. São reconhecidas quinze comunidades distintas de plantas.
Diferentes combinações destas comunidades de plantas são agrupadas em dez paisagens,
que reflectem fortemente a geologia subjacente. As paisagens do Parque Nacional do
Limpopo têm grandes afinidades com algumas encontradas no vizinho Parque Nacional do
Kruger. A principal diferença é a maior representação das paisagens de solos arenosos no


Parque Nacional do Limpopo. Estas constituem 44\% da sua área, o que corresponde a uma área 30 vezes superior à extensão total de paisagens de solos arenosos encontrada no Parque Nacional do Kruger. Isto tem importantes implicações já que assim o Parque Nacional do Limpopo contribui, por si só, para o valor conservacionista do Parque Transfronteiriço. Estratégias de conservação individuais e conjuntas para o Limpopo e para o Kruger têm que ter em conta as diferentes proporções que constituem ambas as áreas em termos das suas paisagens. O método de estabelecimento de paisagens resultou numa caracterização comum dos Parques Nacionais do Kruger e do Limpopo, que pode ser utilizada para a avaliação, gestão e planeamento da conservação no contexto do Transfronteira.

Keywords: Parque Nacional do Limpopo, Kruger National Park, transfrontier conservation area, landscape, sandveld.

M. Stalmans, International Conservation Services, P.O. Box 19139, Nelspruit, 1200, South Africa (stalmans@ics-consulting.co.za); W. Gertenbach P.O. Box 963 Jeffreys Bay, 6330, South Africa (willemg01@telkomsa.net) and F. Carvalho-Serfontein, P.O. Box 655, Maputo, Moçambique (chrisfi@virconn.com).

\section{Introduction}

The Parque Nacional do Limpopo (PNL) was proclaimed during 2002. It covers 1000000 ha in Moçambique on the eastern boundary of the Kruger National Park (KNP) and forms one of the major components of the Great Limpopo Transfrontier Park. A vegetation map was required as one of the essential building blocks for the drafting of its management plan (Grossman \& Holden 2002).

Little or no botanical surveys were carried out in Moçambique between 1980 and 1994 during the long period of internal conflict that affected much of the country (Anonymous 1997). The extent of the area, its relative inaccessibility due to poor road infrastructure, and the limited time available precluded a traditional fine-scale vegetation description and map of the PNL. Such a finescale input is in any case likely to be too detailed for the scale of management envisaged, certainly in the short to medium term.

Vegetation is often used as a surrogate or building block for the definition of habitats (Timberlake et al. 1993). The use of broad habitat units defined by a combination of environmental factors and vegetation would probably represent the most useful input for the drafting of the management plan. This is because such units have relevance to animal species, their availability of water might differ, they might require different fire regimes, and they will differ in their sensitivity to utilisation and development.

Experience in the southwest United States indicates that cover-type maps over wide areas (> $100000 \mathrm{ha}$ ), at reasonable scales (1:100 000 or finer), can take anywhere from three to five years to complete with a modicum of accuracy. They can quickly become very expensive (US\$ 0.40 - \$2.00 per ha) (Muldavin et al. 2001). A quick overview of the relevant phyto-sociological literature in southern Africa reveals that mapping at the plant community level is mostly reserved for protected areas that cover $<10000$ ha. A noteworthy (and applicable) exception is the mapping by Van Rooyen et al. (1981a) of 18 plant communities on 160000 ha in the northern part of the KNP. This required a period of seven months of physical mapping (Dr N. van Rooyen pers. comm. 2003). A larger-scale, feasible and affordable 'landscape' approach was therefore followed. A landscape is defined as 'an area with a specific geomorphology, climate, soil vegetation pattern and associated fauna' (Gertenbach 1983). The landscapes are therefore mapped explicitly whereas the embedded plant communities are implicit.

The objectives of this study were firstly to understand the environmental determinants of the vegetation, secondly to identify and describe individual plant communities in terms of species composition and structure, 


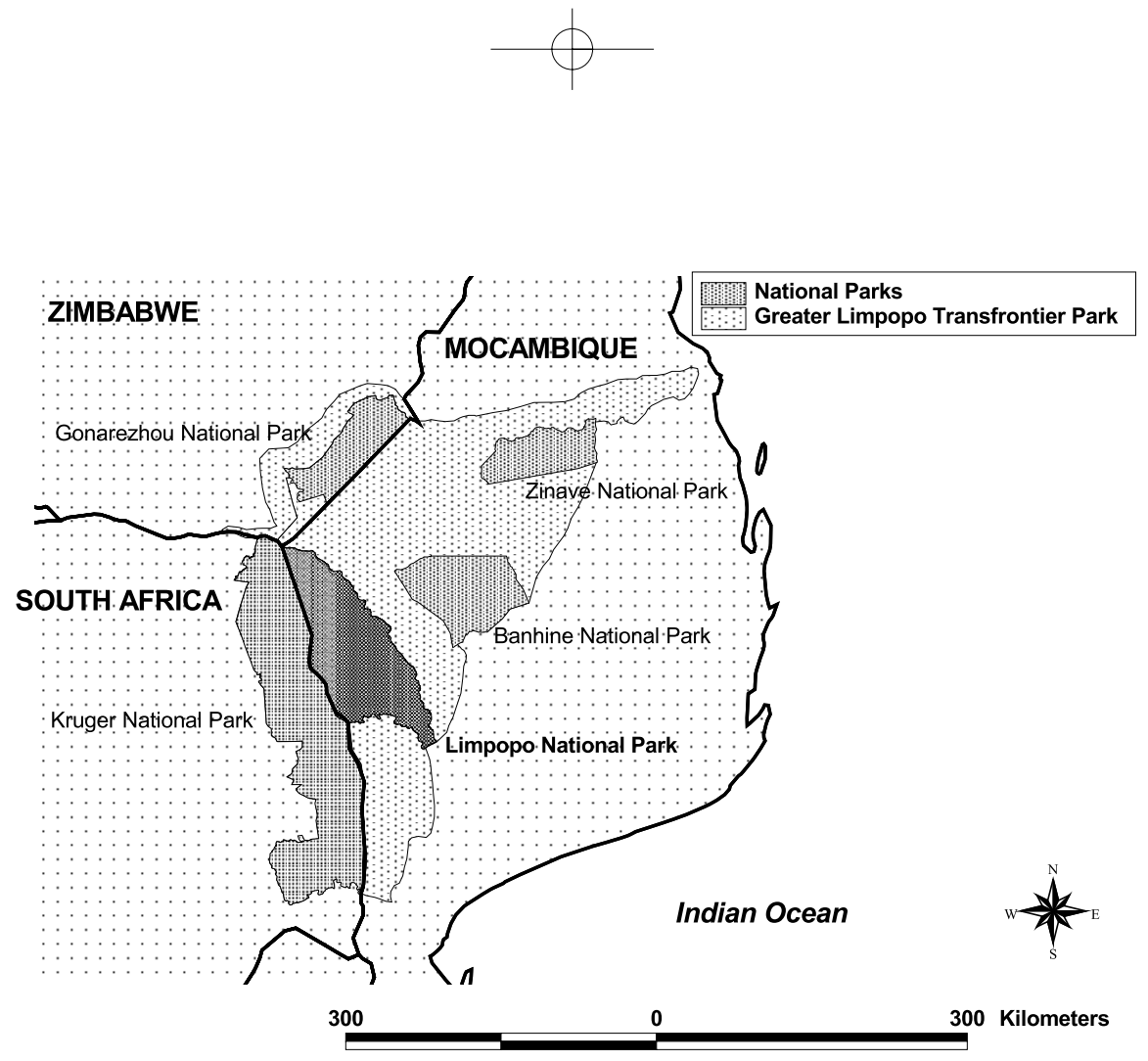

Fig. 1: Locality map of the Parque Nacional do Limpopo.

and thirdly to identify and delineate landscapes in terms of their plant community make-up, environmental determinants and occurrence.

\section{Methods}

\section{Study area}

The physical environment largely determines the vegetation composition and structure. Much detail on the environment of the PNL is available (Anonymous 2001) as well as on the neighbouring and comparable KNP, particularly on climate (Venter \& Gertenbach 1986), geology (Bristow \& Venter 1986) and soils (Venter 1986).

The PNL is situated between latitudes $22^{\circ} 25^{\prime} \mathrm{S}$ $-24^{\circ} 10^{\prime} \mathrm{S}$ and longitude $31^{\circ} 18^{\prime} \mathrm{E}-32^{\circ} 39^{\prime} \mathrm{E}$ in the Gaza Province of Moçambique (Fig. 1). Total area is ca. 1000000 ha. The KNP neighbours the PNL to the west along the international border with South Africa. The Limpopo River forms the northern and eastern border to the PNL, whereas the Olifants River forms the southern boundary.
According to the Koppen classification, the area has a warm arid climate with a dry winter and a mean annual temperature exceeding $18{ }^{\circ} \mathrm{C}$ (Van Rooyen et al. 1981b). Rainfall decreases from $500 \mathrm{~mm}$ annually near Massingir Dam in the south to $<450 \mathrm{~mm}$ at Pafuri in the north. Considerable variations can be expected within and between seasons (Kelly \& Walker 1976). Elevation ranges from $521 \mathrm{~m}$ a.s.l. in the north along the border with the KNP down to $45 \mathrm{~m}$ a.s.l. at the confluence of the Limpopo and Olifants rivers. The dominant geological feature of the PNL is the extensive sandy cover along the northwest/southeast spine of the park. Calcaric sedimentary rocks have been exposed where this sand mantle has been eroded closer to the main drainage lines. Alluvial deposits are found along the main drainage lines (Limpopo, Olifants and Shingwedzi). A narrow tongue of rhyolite rock of volcanic origin straddles the western border with the KNP. Soils derived from the sand mantle range from shallow to deep and are mostly infertile. Deep, structured clay soils are derived from calcaric sedimentary rocks. The alluvial soils are clayey and fertile. Soils derived from the rhyolite are shallow and clayey. The PNL falls within the mopane vegetation of the SudanoZambezian Region as described by Werger \& Coetzee (1978). Mopaneveld has been described for the hot, dry valley bottom of the Limpopo River in 


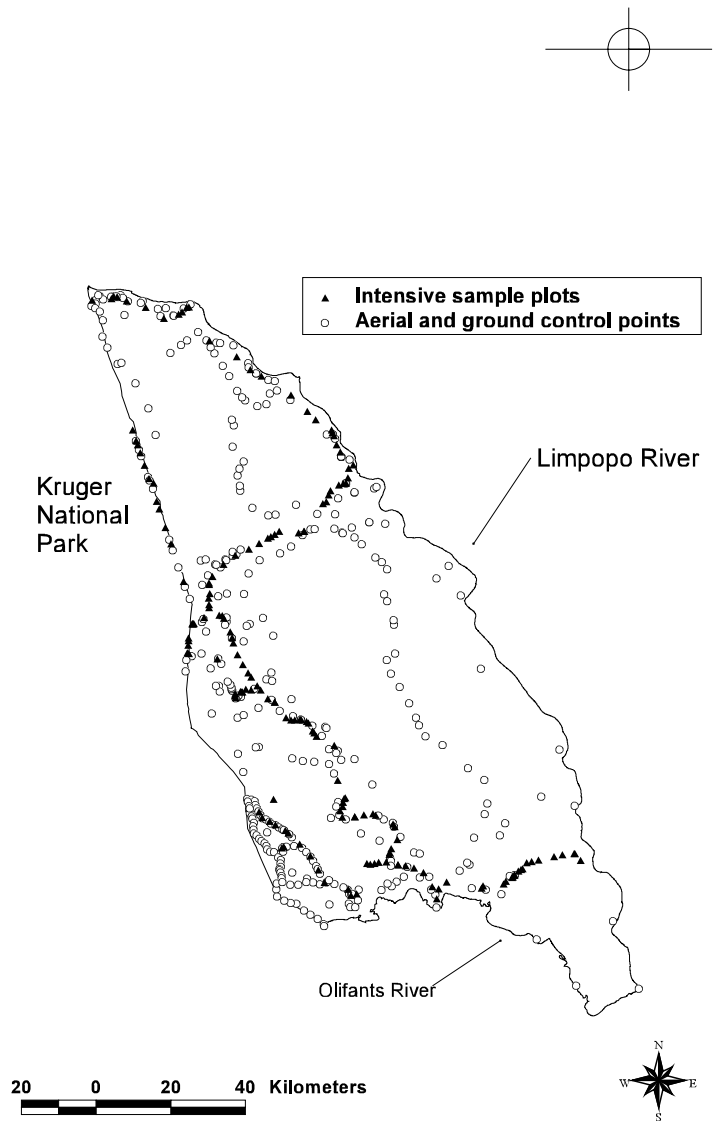

Fig. 2: Position of vegetation sample plots and control points in the Parque Nacional do Limpopo.

Moçambique (Wild \& Barbosa 1967). Within the KNP this corresponds to veld type 15, Mopani veld (Acocks 1988). This veld type has been divided into Mopane Shrubveld, Mopane Bushveld and Lebombo Arid Mountain Bushveld by Low \& Rebelo (1996). Most of the diverse and numerous large herbivore component that would be expected to occur in this area has been lost over the last decades, mostly through indiscriminate and illegal hunting. A significant number of people presently live within the PNL's borders. They are mostly concentrated on the alluvial plains of the Limpopo and Shingwedzi rivers where they practice subsistence cultivation. Livestock comprises cattle and goats. Their numbers are generally low.

\section{Sampling}

A total of 175 plots of 40 x 40 m were subjectively located in representative stands of vegetation so as to cover the variation in geology, elevation and terrain position. The limited road network was used (Fig. 2). Edwards' (1983) structural classes were used to describe the overall structural properties of the sampled plots. Overall cover was estimated for respectively the woody, grass, forb and geophyte component using the semi-quantitative measures of the Braun Blanquet approach (Mueller-Dombois \& Ellenberg 1974). Cover and height classes were recorded for individual woody and grass species. Records of environmental data included GPS position, geology, landscape position, slope steepness, soil texture (using the sausage method (National Working Group for Vegetation Ecology 1986)) and rockiness. Fieldwork was undertaken between February and May 2002.

In order to further increase sampling intensity, so-called 'pseudo-plots' were also used. These consisted of a GPS point, digital photograph and subjective visual assessment relative to the formally surveyed sites. A total of 155 such pseudoplots were assessed (Fig. 2). In addition, a total of 208 points were subjectively assessed from the air during several helicopter flights that were undertaken for planning purposes (Fig. 2).

\section{Analysis}

Data were analysed through a combination of classification and ordination techniques. Classification is used to identify groups and to impose structure to raw data. Ordination aims at arranging species and samples in a low-dimensional space such that similar entities area close by and dissimilar entities far apart.

A TWINSPAN classification (Hill 1979) was performed on the sample data. Two-way indicator species analysis (TWINSPAN) is a polythethic divisive technique based on reciprocal averaging ordination (Gauch 1982). It is one of the preferred hierarchical techniques because of its effectiveness and robustness. It results in the definition of communities each characterised by its own distinctive species combination.

The CANOCO package (ter Braak 1992) was selected to analyse relationships between the data set of 175 plots by 237 species and the underlying environmental factors. CANOCO allows for canonical ordination. This is an intermediate technique that combines aspects of regular ordination with aspects of regression (Jongman et al. 1987). CCA (Canoni- 
cal Correspondence Analysis) was used. The resulting ordination diagram expresses not only the pattern of variation in species composition but also the main features of species distributions along the gradient of environmental variables (ter Braak 1986).

\section{Delineation of landscapes}

Maximum use was made of the accumulated knowledge gained since the first vegetation maps produced in the 1950's (Codd 1951) for the adjoining and similar KNP. The Venter-based land classification system (Venter 1990) seems very appropriate to the environment of the PNL, but requires too much information on soil patterns to be applicable at this stage.

The relevant landscapes for the PNL were identified using the knowledge gained through the ordination and classification of the PNL field data. A combined approach was used to map these landscapes using the available geological map, the existing land cover map and a LANDSAT image. The land cover map ("Carta de Uso e Cobertura da Terra") has been derived for Moçambique a few years ago from LANDSAT satellite imagery at a scale of 1:250 000 . A 'best fit' map of the landscapes was subjectively drawn.

As the greater occurrence of the sandveld landscape in the PNL represents one of the major differences with the KNP and as this has important conservation implications, it was deemed necessary to assess the likelihood that this landscape was accurately mapped. It is a landscape that is currently poorly accessible by vehicle. All land cover polygons that

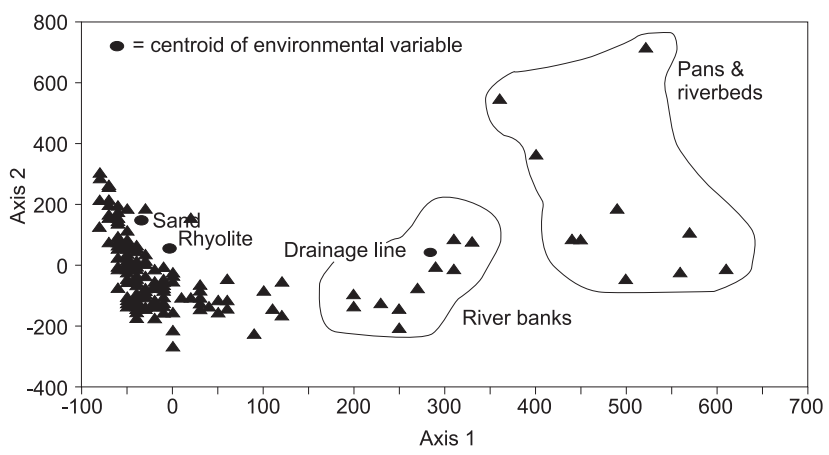

Fig. 3: CANOCO ordination of 175 vegetation sample plots in the Parque Nacional do Limpopo. Note dense cloud of sample plots on left side of diagram with 20 outlying plots to the right that represent vegetation in areas with high moisture availability. fell within sandveld landscapes 30 and 32 were assigned a probability score as to wether they are likely to truly represent sandveld or not. The score was based on the proportion of sample plots or pseudoplots that represented sandveld within each landcover polygon $(\leq 50 \%=$ low probability of correct classification, $51-75 \%=$ medium, $>75 \%=$ high).

\section{Results and discussion}

\section{Causal factors of vegetation pattern in the PNL}

The first ordination run with the full set of 175 vegetation plots resulted in a dense bunch of plots in ordination space with 20 plots as outliers (Fig. 3). The environmental variable 'drainage channel or floodplain' had a high canonical coefficient of 0.94 with the first axis, whereas the variable 'sandy geology' had a canonical coefficient of 0.74 with the second axis.

The 20 outlying plots represent all the pans, riverbanks and reedbeds that were sampled (Fig. 3). The amount of available moisture as determined through landscape position therefore represents a major environmental determinant of vegetation composition along the first ordination axis. The different sample scores of a specific environmental variable are represented within the ordination diagram by a single point, called the 'centroid' (Fig. 3). Species associated with the pans and riverbeds are Acacia xanthophloea and the grasses Eriochloa meyeriana, Sporobolus consimilis, Paspalidium obtusifolium and Eragrostis heteromera. The sample plots on the riverbanks are typified by the woody species Acacia xanthophloea, Faidherbia albida, Ficus sycomorus and Kigelia africana.

The 20 outlying plots were removed from the data set and a new ordination was run. The 


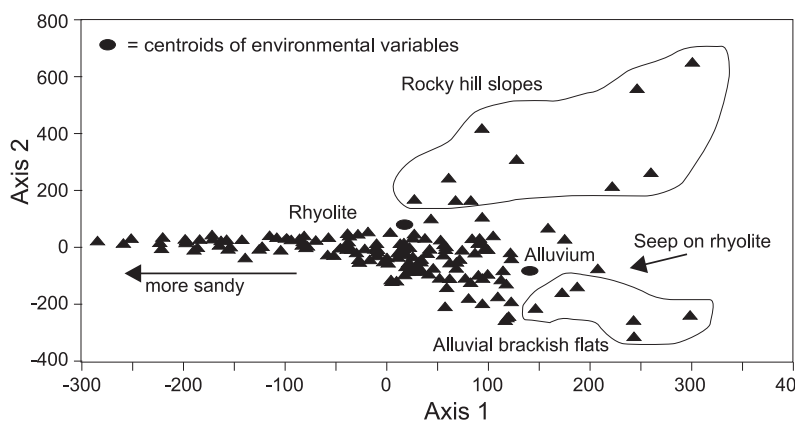

Fig. 4: CANOCO ordination of 155 vegetation sample plots in the Parque Nacional do Limpopo (excluding sample plots along major drainage lines).

resulting diagram displays a soil gradient along the first axis with sample plots in sandveld located on the left-hand side of the diagram and sample plots on heavier soils towards the right-hand side of the diagram (Fig. 4). The second axis separates brackish alluvial flats from rocky hill slopes on rhyolite. Species associated with the alluvial areas are Salvadora persica, Acacia tortilis, Cadaba natalitia, Balanites pedicellaris and Euphorbia ingens. The steep rocky slopes are characterised by Kirkia acuminata, Commiphora edulis, C. tenuipetiolata, Euphorbia cooperi, Albizia brevifolia and Adansonia digitata.
The 16 sample plots that represent brackish flats and rhyolite hills were removed and the remaining data set was re-ordinated. The split between 'sandveld' and non-sandveld sample plots is clear along the gradient of increasing clay content of the soil (Fig. 5). Androstachys johnsonii (Lebombo ironwood or Simbitsi) forests are clearly separated from the main cloud of sandveld plots. Other species typical for the sandveld plots are Xeroderris stuhlmannii, Pteleopsis myrtifolia and Guibourtia conjugata. The non-sandveld sample plots are characterised by Colophospermum mopane (mopane), Acacia nigrescens, Combretum imberbe and Kirkia acuminata.

Further ordination of the 105 sample plots that represent 'mopane veld' did not result in a clear separation in ordination space which points to gradual transitions rather than sharp-edged ecotones. A gradient in clay content that is determined between the interaction of the underlying geological substrate and the landscape position is inferred. One would expect clay content to increase from crest and upper slopes to the bottom of the landscape whilst at the same time clay content increases from alluvium to rhyolite. The heavier clay soils are characterised by the grasses Ischaemum afrum and Setaria incrassata. The woody species Salvadora persica and Acacia tortilis are typical of alluvial soils. Strychnos spinosa is a typical exponent of sandy crests and upper slopes.

The successive ordination runs clearly indicate the overriding importance of moisture availability in determining vegetation composition in the PNL. Firstly, the obvious differences in moisture availability by virtue of sample positions along quasi-perennial or seasonal waterbodies came out of
Fig. 5: CANOCO ordination of 139 vegetation sample plots in the Parque Nacional do Limpopo (excluding sample plots along major drainage lines, rhyolite hills and brackish alluvial flats). 
the first ordination. Thereafter, the gradient in soil clay content (as a result of underlying geological substrate and landscape position) and landscape position per se (in determining water flow) largely determine soil moisture availability. In addition, geology determines intrinsic nutrient potential and landscape position influences nutrient depletion and accumulation processes.

The interplay of soil moisture and soil nutrient availability conforms to the current understanding of the determinants of savanna. The four-determinant model gives water availability and nutrient availability equal status in establishing the range of possible forms a savanna can assume (Scholes \& Walker 1993). Fire and herbivory then determine the actual form and function within that range. Similarly, Timberlake et al. (1993) consider soil moisture in this environment as a major determinant in the distribution of vegetation types. Soil moisture availability results from the interaction between rainfall, topography, soil texture, soil depth, drainage and rooting habit. Siebert et al. (2003) identified a gradient of decreasing soil moisture availability along the first axis of ordination of more than 2000 sample plots in mopane veld straddling South Africa, Namibia and Botswana. Stalmans (1994) identified water availability (as controlled by the position of the sample in the landscape and by its soil texture) as the major determinant of vegetation composition in an area adjacent to the Gonarezhou National Park in Zimbabwe that

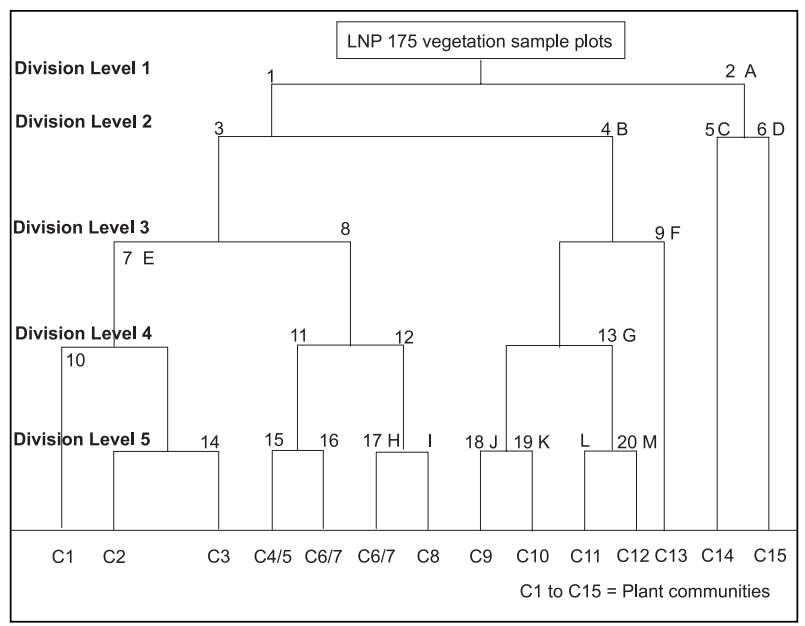

Environmental characteristics

\begin{tabular}{|ll|}
\hline A Drainage lines, floodplains \& & G Riverine \\
pans & H Heavy clay soils \\
B Clayey soils & I Rhyolite of the Lebombo \\
C Floodplain (seasonally & Mountains \\
flooded) & J Calcrete substrate, shallow \\
D Pans (depressions, flooded & soils \\
for long periods) & K Alluvial flats \\
E Deep sandy soils & L Small drainage lines \\
F Seepage on rhyolite & M Banks of large rivers \\
\hline
\end{tabular}

Indicator species for the hierarchical division

1 Colophospermum mopane, Panicum maximum, Urochloa mossambicensis

2 Cynodon dactylon, Eriochloa meyeriana

3 Combretum apiculatum, Colophospermum mopane, Digitaria eriantha

4 Thilachium africanum

5 Acacia xanthophloea

6 Cynodon dactylon

7 Guibourtia conjugata, Baphia massaiensis

8 Colophospermum mopane

9 Eragrostis cf. trichophora

10 Androstachys johnsonii

11 Lannea stuhlmannii, Combretum apiculatum, Pogonarthria squarrosa, Eragrostis rigidior

12 Enneapogon scoparius

13 Acacia xanthophloea

14 Combretum apiculatum

15 Pteleopsis myrtifolia, Combretum apiculatum, Perotis patens, Pogonarthria squarrosa

16 Colophospermum mopane, Eragrostis superba

17 Colophospermum mopane

18 Boscia foetida, Colophospermum mopane

19 Acacia tortilis, Salvadora persica, Urochloa mosambicensis

20 Philenoptera violacea, Acacia schweinfurtii, Fluggea virosa, Grewia flavescens

Fig. 6: TwINSPAN dendrogram for 175 vegetation sample plots in the Parque Nacional do Limpopo. 


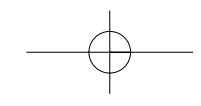

has a rainfall regime broadly similar to the PNL.

The results from the TWINSPAN classification are presented by means of a dendrogram (Fig. 6). Starting from the top of the dendrogram, the set of 175 sample plots was divided into two groups. The left group represents the bulk of the sample plots $(n=168)$. The right group, with indicator species Cynodon dactylon and Eriochloa meyeriana, consists of seven samples representing vegetation found in pans and on other periodically flooded areas.

The second level split divides the group of 168 samples into one of 136 and 32 plots respectively. Combretum apiculatum, Colophospermum mopane, Digitaria eriantha and Schmidtia pappaphoroides are indicator species for the left group. Thilachium africanum is the indicator for the right group. The group of seven samples, resulting from the first level split, is divided into two groups representing respectively open floodplain and pan vegetation.

At the third level, the group of 132 plots is divided into groups of 11 and 125 samples. The left group is characterised by Guibourtia conjugata and Baphia massaiensis. These are typical sandveld species. The right group has Colophospermum mopane as an indicator species.

On the fourth level the sandveld group of 11 plots is further divided into typical closed Androstachys johnsonii forests and open woodland. The group of 125 plots is divided into groups of 53 and 72 plots respectively on the basis of indicator species such as Pogonarthria squarrosa, Lannea schweinfurtii var. stuhlmannii, Enneapogon sp. and Eragrostis rigidior for the left group. The remaining 31 plots of the previous level with Thilachium as indicator are split into groups of 20 and 11 plots respectively with Acacia xanthophloea as indicator for the right-hand split.

At the fifth level the 8 sandveld plots are split on the basis of the importance of Combretum apiculatum. The left hand group con- sists of Baphia massaiensis thickets. The group of 53 plots is split into a sandveld component of 26 plots with Perotis patens, Pteleopsis myrtifolia, Terminalia sericea and Pogonarthria squarrosa as indicators. The right-hand group of 27 plots has Colophospermum mopane (cover of at least 5 to 25\%) and Eragrostis superba as indicator species. Five plots found on steep rhyolite slopes are being split of from the previous group of 72 plots leaving 67 plots on the left. These 5 plots are characterised by an open woodland with Kirkia acuminata and Adansonia digitata. The 20 plots from the previous level are divided into thickets on calcrete and brackish alluvial flats respectively. Boscia foetida and Colophospermum mopane are indicators for the thickets and Salvadora persica, Acacia tortilis and Urochloa mossambicensis are indicators for the alluvial areas. The 11 plots previously indicated by Acacia xantophloea at level 4, are split into a fairly open community on the left and a riverine forest community on the right with indicators Grewia flavescens, Flueggea virosa and Philenoptera violacea.

In summary, the left branches of the dendrogram represent 'sandveld', the middle divisions 'mopane veld' and the right branches vegetation associated with more mesic conditions (river banks, pans).

\section{Definition of plant communities}

The community concept is applied in its broad sense and reflects a recurring assemblage of grass and woody species of characteristic composition and structure, growing in an area of essentially similar environmental conditions and land use history (adapted from Gabriel \& Talbot (1984)).

The classification outcome was evaluated subjectively against photographs of each sample plot. The main criteria applied was the need for each community to be identifiable in the field by an observer who is not necessarily a trained botanist. Community names were chosen subjectively so as to have practical value in the field through the use of two species which are visually and/or 
diagnostically important. The communities broadly conform to the lower divisions of the dendrogram and they are therefore discussed from left to right following Fig. 6. A total of 15 communities were identified.

\section{Description of plant communities}

\section{Community 1: Androstachys johnsonii - Guibourtia conjugata short forest}

This community is probably the most distinctive of all the plant communities found in the PNL. It consists of an extremely dense, short $(5-10 \mathrm{~m})$ forest. Androstachys johnsonii forms a closed canopy. This is a species-poor community with only four woody species and four grasses recorded in the three sample plots. Guibourtia conjugata was the only other woody species with $100 \%$ frequency. Only two other woody species were noted, namely Croton pseudopulchellus and a Vitex sp. Grass cover was generally limted to less than $1 \%$ canopy cover. Panicum maximum had a $100 \%$ frequency. The only other species encountered were Brachiaria deflexa, Perotis patens and Aristida sp. Of interest is the occurrence of Usnea lichen that is draped in the crowns of the trees. The rainfall should be too low for this lichen to occur and therefore moisture (such as from regular mist) rather than rain must play a role (Gertenbach 1983).

This community is generally sharply demarcated from other communities. It occurs in patches ranging from a few dozen meters diameters to large areas covering many hectares. These patches are generally found in sandveld areas. However, significant stands of Androstachys have been observed on steep calcrete slopes and steps leading down to Massingir Dam and the Limpopo River as well as in the Pafuri Hills (Tinley unpubl.).

This community corresponds to the Androstachys johnsonii-Croton pseudopulchellus dry forest described in the northern part of the KNP (Van Rooyen et al. 1981b).
Community 2: Baphia massaiensis -

Guibourtia conjugata low thicket

This community occurs on deep red sandy soils. It consists of a dense shrubby thicket with a canopy of 2-5 m height. Baphia massaiensis occurs as a shrub whereas Guibourtia generally takes a tree form. Both these species, as well as Pteleopsis myrtifolia, Combretum celastroides and Stychnos madagascariensis had a $100 \%$ frequency of occurrence. Other important grass species were Eragrostis pallens, Digitaria eriantha, Stipagrostis uniplumis and Panicum maximum. Other typical sandveld elements are the trees Xeroderris stuhlmannii and Hymenocardia ulmoides. A total of 25 woody and eight grass species were recorded.

This community was only encountered along the Mapai-Macandezulo track, both east and west of Buarinhama Pan. This community links up along the international border to the Nwambia Sandveld in the KNP where the very similar Baphia massaiensis - Guibourtia conjugata thicket was described by Van Rooyen et al. (1981b). This area is very dense and is known as the 'Nyandu Forest' in the KNP (Van der Schijff 1957).

\section{Community 3: Terminalia sericea - \\ Eragrostis pallens low woodland}

This community typically occurs on sandy soils. It is characterised by the ubiquitous nature of Terminalia sericea and Pogonarthria squarrosa, coupled to an absence of any Colophospermum mopane. The latter characteristic distinguishes this particular sandveld community from community 4 . Other species with a $100 \%$ frequency were Combretum apiculatum, Eragrostis pallens and Panicum maximum. Other typical sandveld species such as Guibourtia conjugata, Xeroderris stuhlmannii, Baphia massaiensis, Pteleopsis myrtifolia and Hugonia orientalis occurred at lower frequencies. A total of 26 woody and 12 grass species were recorded in the three sample plots belonging to this community. This community is therefore more species rich than the Baphia massaiensis thickets. 
This woodland community was found along the main sandy spine of the PNL. It is very likely that this community is widespread along this sandy spine in between the sampled localities. Poor road access makes it difficult to map the actual extent of this community. Structurally this community is difficult to separate from community 4, thereby making an aerial assessment of its extent difficult.

This particular community very closely resembles the Terminalia sericea - Pogonarthria squarrosa tree savanna identified in the Punda Maria area of the KNP (Van Rooyen et al. 1981b). Community 3 also encompasses the Xeroderris stuhlmannii Combretum apiculatum tree savanna of Van Rooyen et al. (1981b).

\section{Community 4: Combretum apiculatum - Pogonarthria squarrosa low woodland}

Community 4 is in some respects very similar to community 3 . The major difference is a sizeable frequency of occurrence of Colophospermum mopane, which is absent from community 3. Nevertheless it is still a 'sandveld' community. This is evident by the presence of Pteleopsis myrtifolia, Xeroderris stuhlmannii, Combretum celastroides and Eragrostis pallens. These species are also found in sandveld communities 2 and 3, but not at all in the typical mopane woodlands of community 6. The two sandveld species Guibourtia conjugata and Stipagrostis uniplumis were only recorded once each in the 78 sample plots of community 6 . A total of 65 woody and 20 grass species were recorded in the 21 sample plots belonging to this community. It is possible that this community corresponds to the patches of mopane (Terminalia sericea - Colophospermum mopane community) found by Siebert et al. (2003) in sandveld.

Community 4 is found along the sandy spine of the PNL and most conspiciously on the sandy substrates in the southwestern part of the PNL, near Massingir Velho.
Community 5: Combretum apiculatum Andropogon gayanus low woodland

This community has affinities to the previous community. It occurs however on shallow, rocky soils which are derived from rhyolites. Soils are loamy to clayey, but do not consist of the deep clayey soils found in other rhyolite areas. Typical localities are on the crest of the Lebombo Mountains near Giriyondo Gate.

The vegetation is characterised by Combretum apiculatum and the grass Andropogon gayanus. Stunted Albizia petersiana represent one of the affinities with sandveld community 4 . A total of 22 woody and 13 grass species were recorded in the 6 sample plots belonging to this community.

\section{Community 6: Colophospermum mopane - Panicum maximum short woodland}

This community represents the typical mopane woodlands associated with the PNL. Much variation is encountered within these woodlands. The gradation is however often not abrupt and although four main variants may be recognised it is difficult for field work purposes to handle those separately.

The four main variants are largely based on underlying geology; calcrete, sand, rhyolite and alluvium. All variants are dominated by Colophospermum mopane and have as main grass species Panicum maximum, Urochloa mossambicensis and Schmidtia pappaphoroides. The variant on calcrete is characterised by the frequent occurrence of Enneapogon scoparius. This variant corresponds to the Colophospermum mopane - Enneapogon scoparius shrub savanna identified by Van Rooyen et al. (1981c). The variant on sandy substrates has Combretum apiculatum as an important component. On alluvial soils, Acacia nigrescens appears. On rhyolites, both Acacia nigrescens and Heteropogon contortus are obvious.

The mopane woodlands appear at first sight to be the most widespread community of the PNL. This is because of the network of roads and tracks being mostly situated on the eco- 
tone between the alluvial and calcrete areas thereby traversing mopane veld rather than the sandveld that covers the greater extent of the PNL. A total of 101 woody and 36 grass species were recorded in the 78 sample plots belonging to this community.

\section{Community 7: Colophospermum mopane - Combretum imberbe tall shrubland}

This community occurs on clays, mostly derived from rhyolite but to a lesser extent derived from calcrete. This community typically consists of stunted Colophospermum mopane. These stunted specimens may occur in dense stands or as sparse individuals. Other typical woody species are Acacia nigrescens, Sclerocarya birrea and Combretum imberbe. Vegetation of clays has several highly exclusive species such as Setaria incrassata and Ischaemum afrum (Coetzee 1983; Farrell 1968). This community is similar to the Colophospermum mopane Themeda triandra shrub savanna on clay soils of basalts and andesites in the KNP (Van Rooyen et al. 1981c). A total of 21 woody and 17 grass species were recorded in the 13 sample plots belonging to this community.

\section{Community 8: Kirkia acuminata- Combre- tum apiculatum tall woodland}

This woodland is found on moderately to very steep, rocky, rhyolite slopes as well as to a lesser degree on steep basalt hills in the vicinity of Pafuri. The vegetation consists of a tall woodland with Kirkia acuminata and Adansonia digitata as the most distinct species. Commiphora tenuipetiolata is confined to this community. Van Rooyen et al. (1981c) describe a similar community on basalt slopes in the northern part of the KNP as Colophospermum mopane - Commiphora glandulosa - Seddera capensis open tree savanna. A total of 53 woody and 14 grass species were recorded in the nine sample plots belonging to this community.
Community 9: Terminalia prunioides -

Grewia bicolor thicket

These thickets are mostly found on calcrete areas on shallow, stony soils that are probably very xeric. Terminalia prunioides is the most prominent woody species, second in average cover only to the shrub Grewia bicolor. The succulents Euphorbia grandidens and Cissus quadrangularis are conspicuous. A total of 41 woody and eight grass species were recorded in the five sample plots belonging to this community. The number of woody species is relatively high, but the grasses are less prominent due to the closed nature of the woody canopy.

\section{Community 10: Acacia tortilis - Salvadora persica short woodland}

This represents one of the most important communities from a human and animal perspective on account of its high fertility status and proximity to the water of the large rivers. It typically consists of an open woodland with Acacia tortilis with its characteristic umbrella-shaped canopy as the most recognizable element. Salvadora persica is the diagnostic species for this community. This is still considered as one of the 'mopane' veld communities and was classified by Van Rooyen et al. (1981c) as the Colophospermum mopane - Acacia tortilis - Urochloa mossambicensis tree savanna.

This community is strictly confined to alluvial flats along the Limpopo, Olifants and Shingwedzi rivers. These areas tend to be brackish in places, in particular below the Massingir Dam, where atypical, shrubby examples of this community occur. A total of 44 woody and 16 grass species were recorded in the 13 sample plots belonging to this community.

\section{Community 11: Acacia xanthophloea - Phragmites sp. woodland}

This community typically fringes the smaller rivers. It generally consists of a narrow fringe of Acacia xanthophloea woodland on the banks with an inner section dominated by 
grasses (including reeds) and sedges on the lower banks and in the river. A sharp contrast can sometimes be observed between the occurrence within a few meters of each other of Eriochloa meyeriana in very damp conditions and Danthaniopsis parva in very dry conditions on exposed rocks. A total of 20 woody and 14 grass species were recorded in the six sample plots belonging to this community.

\section{Community 12: Acacia xanthophloea - Faid-} herbia albida tall forest

In contrast to the previous community, this community is more commonly found along the larger rivers. It is particularly prominent above Mapai along the Limpopo River. It consists of a tall forest with large trees. This community seems to occur in areas that are less prone to flooding than communities 11 , 14 and 15 (Tinley unpubl.). This forest corresponds to the Acacia albida - Ficus sycomorus riverine forest along the Limpopo and Levubu rivers in the KNP (Van Rooyen et al. 1981a). A total of 36 woody and 10 grass species were recorded in the five sample plots belonging to this community.

\section{Community 13: Setaria incrassata short grassland}

This represents probably the smallest community in the PNL in terms of its total extent. It is, however, one of the physiognomically most distinct communities found. It occurs as small patches of less than one hectare in extent, totally devoid of trees on account of being waterlogged through seepage from rhyolite slopes. The boundary with the surrounding mopane woodlands of community 6 is very abrupt. The grasslayer is dominated by Setaria incrassata.

\section{Community 14: Sporobolus consimilis - Setaria incrassata tall grassland}

This community is found in seasonally waterlogged areas. These might be as a result of flooding (for example along the Limpopo River near Pafuri) or from the filling of pans from rain. These areas do however become dry again, in contrast to community 15 . As a result of the waterlogged soils, the woody component is limited. The grass layer is very dense and tall. Dominant species are Sporobolus consimilis (sometimes in almost monospecific stands) and Setaria incrassata. Van Rooyen et al. (1981a) similarly described Sporobolus consimilis grassland for the Limpopo floodplain in the KNP. A total of four woody and six grass species were recorded in the four sample plots belonging to this community.

Community 15: Paspalidium obtusifolium Cynodon dactylon grassland

This community is found in areas that are flooded for longer periods than the previous community. The sample sites that were surveyed were at some of the larger pans and in one of the inlets of the Massingir Dam. The waterlogged nature of the soils impedes tree growth. Typically, the vegetation will consist of a floating mat of Paspalidium when flooded with a fringe of Cynodon dactylon and Eragrostis heteromera. A total of three woody and eight grass species were recorded in the three sample plots belonging to this community.

\section{Landscapes of the PNL}

Subjective comparison of the results of the vegetation survey led to the conclusion that the landscapes found in the PNL can be usefully described using the same landscapes as previously defined by Gertenbach (1983) in the KNP. The following 10 landscapes can be recognized in the PNL (see Fig. 7 for their distribution):

\section{Landscape no. $32 \quad$ Nwambia Sandveld}

This landscape covers approximately 458641 ha (41.1\% of PNL). It stretches from the northwestern border with the KNP in a southeasterly direction down towards the confluence of the Limpopo and Olifants Rivers. It is found on sandy substrates, including deep red soils of the red sandy mantle dunes of the interior. A characteristic 

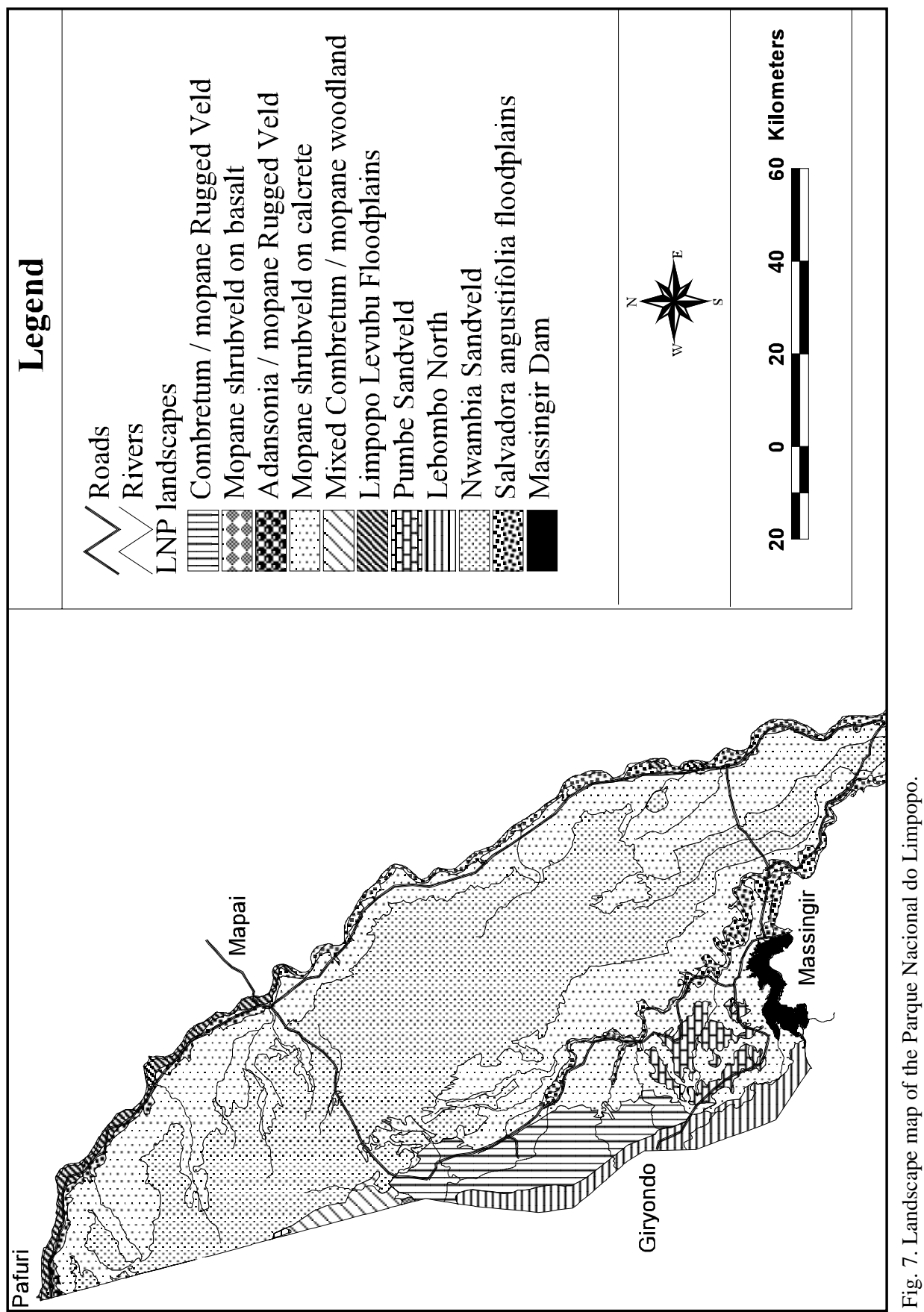
Table 1

Crosstabulation between plant communities (of the sample plots) and underlying geological substrate

\begin{tabular}{lcccc}
\hline & Sandy geology & Alluvium & Calcrete & Rhyolite \\
\hline Sandveld communities & $72 \%$ & $0 \%$ & $22 \%$ & $6 \%$ \\
Mopane communities & $9.7 \%$ & $19.4 \%$ & $48.4 \%$ & $2.2 \%$ \\
Alluvial community & $0 \%$ & $50 \%$ & $46.6 \%$ & $0.4 \%$ \\
\hline
\end{tabular}

of the geomorphology is an absence of welldefined drainage channels and the presence of a variety of pans (Gertenbach 1983). The make-up in terms of plant communities (in descending order of importance) is predominantly communities 3, 4 and 2. Small and large patches of community 1 are embedded in the previous communities. Patches of the sandy variant of community 6 occur. Community 15 is found in and around pans.

\section{Landscape no. $30 \quad$ Pumbe Sandveld}

This landscape is very similar to the Nwambia Sandveld. However, the proximity to Pumbe, contact with rhyolites, and likely slightly higher rainfall suggest a closer affinity with the Pumbe Sandveld than with Nwambia. The recommended local name for PNL is 'Massingir Velho Sandveld'. It covers approximately 25608 ha (2.3\% of PNL) and is found in the southwestern section of the PNL, to the northwest of Massingir Velho. This landscape is mainly made up by communities 3 and 4, with patches of the sandy variant of community 6 . None of the latter is found in the Pumbe Sandveld in the KNP.

Landscape no. 25

Adansonia digitata/ Colophospermum mopane Rugged Veld

This landscape that occurs in the extreme northwestern part of PNL at Pafuri covers approximately 1219 ha ( $0.1 \%$ of PNL). It consists of rocky hill slopes on basalts and calcrete. Annual rainfall is low ( $<450 \mathrm{~mm})$. The soils are shallow and calcareous with a fair amount of clay. The landscape is made up by communities 8,9 , and the calcrete variant of community 6 .

\section{Landscape no. 26 Colophospermum mopane Shrubveld on Calcrete}

This landscape of 415890 ha (38.8\% of PNL) is distributed along north-south lines above the Limpopo Valley, and on both sides of the Shingwedzi Valley. It occupies the sedimentary footslopes and ravines with calcareous pebble-beds. Soils are shallow and calcareous. The dominant plant community is the calcrete variant of community 6 . Other components are communities 7, 9, 14 (found on the pans in the mopane), and patches of community 1 , mainly on the steep slopes above Massingir Dam.

Landscape no. 22

Combretum spp. I Colophospermum mopane Rugged Veld

This landscape is limited in extent and covers only 69911 ha (6.21\% of PNL). It is distributed north and south of the Shingwedzi River as it enters the PNL from the KNP. This landscape is characterized by relatively shallow soils, with skeletal soils on the Lebombo rhyolites of the hills slopes with deeper, clayey soils in the low-lying areas. The plant community comprises mostly communities 8, 7 and 6 (rhyolite variant). Typically, the upper rhyolite slopes would carry community 8 , whereas the footslope with the vertic clays would consist of community 7. An abrupt and drastic increase in both clay and adsorbed cations occurs at the contact between midslopes and footslopes in B-horizons which is caused by the abrupt transition between sand and clay in this posi- 
tion. The exchangeable cations show a further increase as one proceeds down along some of the longer footslopes (Venter 1990).

\section{Landscape no. 23 Colophospermum mopane} Shrubveld on Basalt

This landscape extends marginally from the KNP into the PNL north of the Shingwedzi River. It only covers 271 ha $(0.02 \%$ of PNL). It occurs on basalts that have developed dark colored soils with vertic characteristics and is made up by community 7 .

\section{Landscape no. 27 Mixed Combretum spp./ Colophospermum mopane Woodland}

This landscape of approximately 10576 ha ( $0.94 \%$ of PNL) occurs north of the Shingwedzi River between the border with the KNP and the large sandveld expanse to the east. It occupies soils of mixed origin that consists of weathered products of basalt, Quaternary sand and gravel. It is mostly made up by the sandy variant of community 6 .

Landscape no. 31

Lebombo North

This landscape straddles the border with the KNP. It covers approximately 39878 ha (3.5\% of PNL) along the western boundary with the KNP, south of the Shingwedzi River, with a few isolated outcrops north of the river. The surface is extremely stony with shallow soils derived from rhyolite. Large rocky outcrops occur. An extremely characteristic erosion pattern has developed with right-angled drainage lines. The plant community make-up consists of communities 5, the rhyolite variant of community 6 , community 13 occurring on small seepages, and community 8.

Landscape no. 28

\section{Limpopo Levubu Floodplains}

This landscape of 17292 ha (1.5\% of PNL) stretches along the upper Limpopo River from Pafuri southwards to Mapai. The underlying material is alluvium. This land-
Table 2

Surface area of the landscapes common to the KNP and PNL

\begin{tabular}{cccc}
\hline Landscapes & $\begin{array}{c}\text { KNP } \\
\text { (ha) }\end{array}$ & $\begin{array}{c}\text { PNL } \\
\text { (ha) }\end{array}$ & $\begin{array}{c}\text { PNL as \% } \\
\text { of KNP }\end{array}$ \\
\hline 22 & 80736 & 69911 & 86.6 \\
23 & 199918 & 271 & 0.1 \\
25 & 32304 & 1219 & 3.8 \\
$\mathbf{2 6}$ & 10716 & 415890 & 3881 \\
27 & 33131 & 10576 & 31.9 \\
28 & 9571 & 17292 & 180.7 \\
$\mathbf{3 0}$ & 2548 & 25608 & 1004.9 \\
31 & 55470 & 39878 & 71.9 \\
$\mathbf{3 2}$ & 15789 & 458642 & 2904 \\
35 & 16656 & 76692 & 460.4 \\
\hline
\end{tabular}

scape is subject to flooding. The following plant communities are found: 12, 14 in areas that are regularly flooded, 15 in and around pans that are left after flooding, 11 in river beds, and community 10 in drier parts of the landscape.

\section{Landscape no. $35 \quad$ Salvadora angustifolia Floodplains}

This is the typical landscape of the alluvial flats along the Shingwedzi River, Limpopo River south of Mapai and Olifants River. Its total extent is approximately 76692 ha ( $6.81 \%$ of PNL). As a result of the accumulation of salts in the alluvium, the soils of this landscape are usually brackish (Gertenbach 1983). White salt deposits are sometimes detectable on the surface of the soil. It is mostly made up of communities 10 , with lesser areas of 14, 6 (alluvium variant), 11 in riverbeds and 12 in isolated pockets. The latter is found along the lower Shingwedzi River.

\section{Landscape pattern}

The cross tabulation between the actual vegetation type and the geological substrate on which the sample plots were located, generally yielded the expected results for sandveld (Table 1). Lower matching figures are 
obtained for the alluvial and mopane communities. The reason for the partial mismatch might be that either communities are not strictly defined by the underlying geological substrate or that the available GIS coverage of the geological substrate is imperfect. The sandveld communities are exclusively limited to sandy substrates. However, the sandy substrates do not exclusively carry sandveld communities but also patches of mopane. Most of the sample plots showing a mismatch with the substrate are actually closely located to their 'expected' substrate according to the GIS data. This particularly applies to the alluvial vegetation supposedly occurring on calcrete. The alluvium is defined as a small narrow strip along the main rivers. Small mapping errors would explain the mismatch. A sample plot of alluvial vegetation in the upper reaches of the Shingwedzi River was supposedly found on rhyolite. It was however located on alluvium whereas the geological map does not indicate the presence of alluvium.

The underlying geological substrate thus serves an important predictive role in terms of expected broad communities occurring. It is however not sufficiently accurate nor can it be used as the sole determinant for larger-scale landscapes. The available landcover data (Carta de Uso e Cobertura da Terra) describe a large area along the north-western border with the KNP as mopane veld. It forms an extension of the 'Nyandu forest' found in the KNP. Based on field sampling and aerial surveys, it is clear that this area is covered by sandveld, more particularly dense Baphia thickets. The similarity in spectral signature on the satellite image might be due to this specific sandveld being denser than most of the other sandveld and thus being more similar in structure to the fairly closed canopy of mopane woodlands. This example demonstrates that great care should be used in applying

Koedoe 47/2 (2004) the available landcover data to map landscapes. The units identified in the landcover undoubtedly make sense, but their interpretation is unreliable, probably because of insufficient groundtruthing being possible at a local scale for a project that was originally undertaken at a national scale.

The map boundaries are drawn subjectively because of the fact that there is seldom a definite and visible border between landscapes, but rather a gradient. A small extent of landscape 15 Colophospermum mopane Forest is found on the north western border with the KNP. Its occurrence within the PNL could not be confirmed due to the difficult accessibility of this area. If it occurs at all it would only cover a small area.

The outcome of the mapping is depicted in Fig. 7. The KNP and PNL harbour the same landscapes, but their relative cover is very different. In particular, the sandveld landscapes and the mopane on

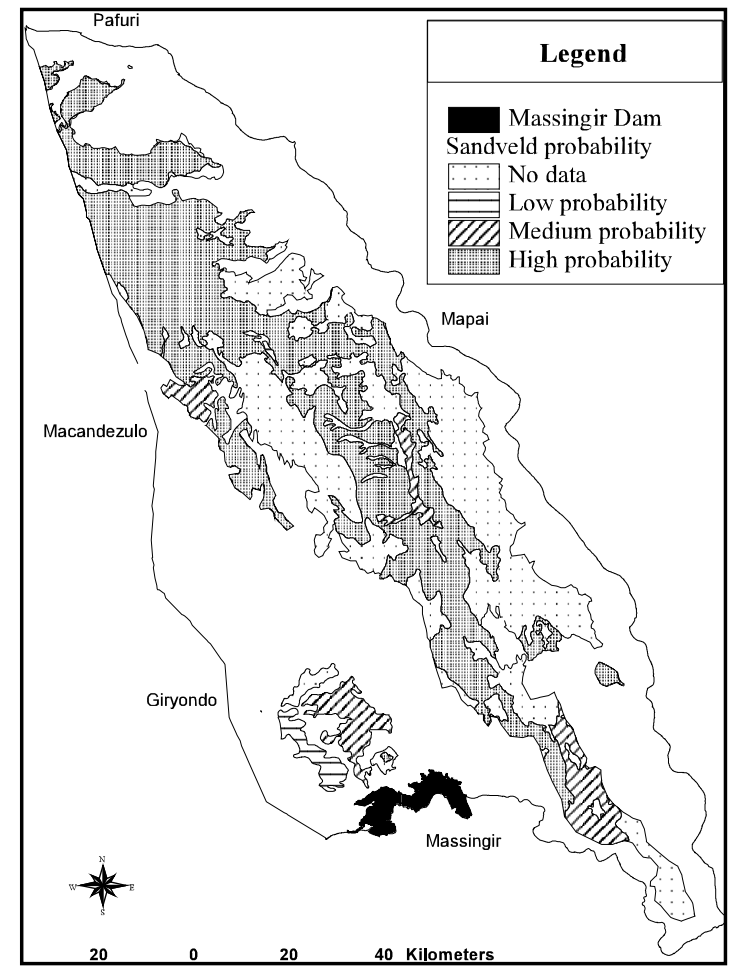

Fig. 8: Probability assessment for the sandveld landscapes in the Parque Nacional do Limpopo.

76

ISSN 0075-6458 
Table 3

Relative species richness of plant communities in the PNL

\begin{tabular}{lccccc}
\hline Community & $\begin{array}{c}\text { No. of } \\
\text { sample } \\
\text { plots }\end{array}$ & $\begin{array}{c}\text { Total } \\
\text { species }\end{array}$ & $\begin{array}{c}\text { Expected } \\
\text { no. } \\
\text { of species }\end{array}$ & $\begin{array}{c}\text { Actual } \\
\text { no.as \% } \\
\text { of expected }\end{array}$ & $\begin{array}{c}\text { Relative } \\
\text { diversity }\end{array}$ \\
\hline 1 & 3 & 8 & 16 & 48.6 & Low \\
2 & 5 & 33 & 27 & 120.2 & High \\
3 & 3 & 38 & 16 & 230.6 & High \\
4 & 21 & 85 & 115 & 73.7 & Low \\
5 & 6 & 35 & 33 & 106.2 & Medium \\
6 & 78 & 137 & 428 & 32.0 & Low \\
7 & 13 & 38 & 71 & 53.2 & Low \\
8 & 9 & 67 & 49 & 135.5 & High \\
9 & 5 & 49 & 27 & 178.4 & High \\
10 & 13 & 60 & 71 & 84.0 & Low \\
11 & 6 & 34 & 33 & 103.2 & Medium \\
12 & 5 & 46 & 27 & 167.5 & High \\
13 & 1 & 3 & 5 & 54.6 & Low \\
14 & 4 & 10 & 22 & 45.5 & Low \\
15 & 3 & 11 & 16 & 66.8 & Low \\
\hline
\end{tabular}

calcrete are much more widespread in the PNL (Table 2). These landscapes cover 10-30 times larger areas in the PNL. More than $50 \%$ of the land cover polygons within this landscape were ranked as having a high probability of truly representing sandveld (Fig. 8). The large extent of sandveld and the high probability of its classification being correct, has important implications. The PNL contributes in its own right to the conservation value of the Transfrontier Conservation Area. Management strategies for the PNL and KNP individually and jointly need to take into account the different proportional make-up of both areas in terms of their landscapes. Neither one of the areas is an 'extension' of the other. The KNP and PNL clearly complement each other.

\section{Plant species of conservation importance}

The methodology followed and the scale and intensity of the survey undertaken, precluded a detailed assessment of rare species. The Red-listed tree Stadmannia oppositifolia ssp. rhodesiaca was observed on cliffs overlooking the Shingwedzi River in community 8 (Kirkia acuminata - Combretum apiculatum tall woodland). Nowhere common, this subspecies is found relatively widely on hills in the Zimbabwe lowveld, in adjacent parts of Moçambique and into the Limpopo Province, South Africa. Records from KwaZulu-Natal need confirmation (HiltonTaylor 2000). It is listed as 'Lower Risk/near threatened' (Golding 2002).

The tree Pterocarpus lucens ssp. antunesii was found in sandveld community 4 in the south eastern section of the PNL. This is considered a very rare tree in the KNP (Van Wyk 1973; KNP staff pers. comm. 2002). It is, however, much more widespread outside South Africa and occurs further north into Africa in the Sudanian savannas of Senegal and Cameroon (Geerling 1982).

A host of other species are considered rare or typical sandveld species, with associated conservation value because of their restricted distribution in the KNP. It is important to note that the current understanding and value judgement on so-called 'rare sandveld endemics' is largely based on this South African perspective. These species occur in the limited extent of Nwambia Sandveld in the KNP. Rather than regarding the PNL 
sandveld as an extension of the Nwambia Sandveld, the appropriate view would be to see the Nwambia Sandveld in the KNP as a small extension of the PNL sandveld. The Nwambia landscape constitutes the single largest landscape of the PNL. Within a true transfrontier context, species such as Pterocarpus lucens might acquire a very different status compared to their position in the KNP only.

\section{Plant community and landscape diversity}

The available time frame and limited ground coverage did not allow for a detailed inventory of plant diversity. However, a relative measure of plant community diversity can be derived by comparing the total species count to the sampling intensity for each respective community. The species count per community in relation to the expected species number (based on the average accumulated number of species per sample plot) is depicted in Table 3. Sandveld communities 2 (Baphia massaiensis - Guibourtia conjugata low thickets) and 3 (Terminalia sericea - Eragrostis pallens low woodland), the rhyolite community 8 (Kirkia acuminata - Combretum apiculatum tall woodland) as well as the closed formations of community 9 (Terminalia prunioides - Grewia bicolor thicket) and community 12 (Acacia xanthophloea - Faidherbia albida tall forest) are relatively more species-rich than the other communities.

Based on the composition of the landscapes in terms of plant communities it can be expected that Landscape no. 32 (Nwambia Sandveld), Landscape no. 25 (Adansonia digitata / Colophospermum mopane Rugged Veld) and Landscape no. 31 (Lebombo North) are relatively richer than other landscapes.

Land use patterns and their influence on the vegetation of the PNL

The available landcover data and field surveys confirm that the highest density of people and agricultural activity is found along the Limpopo, Olifants and Shingwedzi
Rivers. Subsistence cultivation is practiced. According to the land cover data, a total of 26330 ha of land cover units are partly cultivated and/or settled. Using the average percentage transformation within those units, an effective 6795 ha is cultivated. This is likely an underestimate. The more fertile areas on alluvium seem to remain almost permanently under cultivation with only short fallow cycles. Agriculture in less fertile parts of the landscape seems to be more of a shifting nature. Lands are cleared, cultivated for a few years and then abandoned for a long time period.

The abandonment of lands and the fallow cycle result in a number of regeneration states being found throughout the PNL. The most distinct are mopane shrubland following regeneration on cleared mopane woodlands of community 6 (Colophospermum mopane - Panicum maximum short woodland) and an open woodland with large Sclerocarya birrea, Berchemia discolor, Cassia abbreviata, Acacia tortilis, Colophospermum mopane trees and an understorey of Urochloa mossambicensis and Panicum maximum grass on the sites of abandoned settlements. Dichrostachys cinerea and Dalbergia melanoxylon in association with Colophospermum mopane might also represent regeneration on formerly cultivated areas (Farrell 1968).

Clearing is presently still actively taking place, even in sensitive and species-rich areas such as the riverine forest of community 12 (Acacia xanthophloea - Faidherbia albida tall forest) and locally in the sandveld of community 4 (Combretum apiculatum Pogonarthria squarrosa low woodland).

Levels of herbivory (both grazing and browsing) seem presently very limited in the PNL. The subjective scoring of the sample plots yielded the following results: subjected to only light grazing pressure $75.4 \%$, medium grazing $16.6 \%$, heavily grazed $8 \%$. The heavily grazed areas are located close to the villages.

The PNL, being situated downstream from the KNP, is much at risk from alien plants. 
The most serious invaders in the KNP include Chromolaena odorata, Lantana camara, Opuntia stricta, Ricinus communis and Senna spp.

During the present vegetation survey the following invasive alien species were observed: Nicotiana glauca (on the banks of Massingir Dam), Parkinsonia aculeata (in the Limpopo floodplain near Pafuri), Ricinus communis (along the Limpopo River near Mapai), Agave sp. (along the upper Shingwedzi), and Xanthium strumarium (riverine areas). The Limpopo River near Pafuri is more than likely infested by the following waterweeds; Pistia stratiotes, Salvinia molesta and Azolla filiculoides which are all found in the Limpopo River within the KNP (David Zeller pers. comm. 2002).

No formal assessment was made, but much use is clearly made of trees for the building of dwellings, livestock pens, fuel wood and carving of various items. Whereas this use does not seem to impact significantly on the overall woody resource, no data are available on the impact on specific species. Grass is cut and used for thatching (mostly Themeda triandra). Much use is made of medicinal plants and wild fruits. No data are available regarding the impact thereof on specific species.

Fires are very prominent within the PNL with signs of old and recent fire events visible throughout the landscape. Although a number of fires must originate through lightning, the most probable cause of fire is through the activities of the inhabitants of the PNL (clearing of lands, producing a green flush for livestock grazing, smoking out of beehives etc.). Within the constraints of the present study it was not possible to assess the fire return period and its appropriateness. Of interest is the relatively smallscale pattern that can be observed in the field. This is confirmed by satellite imagery. This small-scale pattern as opposed to a larger scale pattern often found in formally managed protected areas is typical of communal areas. This pattern of spatially and temporally varying fire parameters (frequency, sea- sonality, intensity and type of fire) across the landscape is likely to be required for the maintenance of diversity (Brockett et al. 2001; Gill \& McCarthy 1998).

\section{Limitations and recommendations}

The superficial nature of this study must be put in perspective when compared with the KNP where the first vegetation descriptions and maps were already generated during the 1950s.

Poor accessibility to in particular the main sandveld landscape resulted in an uneven coverage of the study area. Although it is believed that the main pattern of vegetation has been adequately captured, the landscape map needs to be refined. Recommendations for further vegetation work include the following: firstly, a ground traverse of the NWSE sandveld spine of the PNL, secondly, using aerial and/or ground assessment of socalled mopane units (according to the 1:250 000 land cover map) and other polygons that received a low probability score in the Nwambia Sandveld to establish their true character, thirdly establish the true position of the interface between landscapes 31 and 22 on the rhyolites, fourthly initiate studies on fence-line contrasts on the western border of the PNL with the KNP as early as possible to capture the effects of differential fire management and stocking rates and lastly implement long-term monitoring programmes on vegetation structure, composition and condition. The fence-line contrasts in particular hold potentially much information for a better understanding of management effects. They should be studied before differences get blurred as a result of the new management regime in the PNL and increases in animal numbers.

\section{Acknowledgements}

The Direcção Nacional de Áreas de Conservação of the Ministério do Turismo, Moçambique, the Peace Parks Foundation and the Parque Nacional do Limpopo are acknowledged for initiating and supporting the study. Park Warden Gilberto Vincente and Project Manager Arrie van Wyk provided logis- 
tical and institutional support. Craig Beech assisted with GIS data. Staff of SanParks including Danie Pienaar, Harry Biggs, Nick Zambatis, Holger Eckhardt and David Woods provided input on the draft and supplied GIS information. Mervyn Lötter, Ernst Schmidt, Warren McLeland and John Burrows of the Plant Specialist Group assisted with species identification. The manuscript benefited from the comments received from two anonymous referees.

\section{References}

AcocKs, J.P.H. 1988. Veld types of South Africa. 3rd ed. Memoirs of the botanical Survey of South Africa 57: 1-146.

ANONYMOUs, 1997. First national report on the conservation of biological diversity in Mozambique. Maputo: Ministry for the Coordination of Environmental Affairs.

ANONYMOUs, 2001. Land use planning of Coutada 16. Part of the Gaza-Kruger-Gonarezhou Transfrontier Park. Unpublished report by the Peace Parks Foundation.

Bristow, J.W. \& F.J. Venter. 1986. Notes on the Permian to recent geology of the Kruger National Park. Koedoe 29: 85-104.

BrocketT, B.H., H.C. Biggs \& B.W. van WiLgen. 2001. A patch mosaic burning system for conservation areas in southern African savannas. International Journal of Wildland Fire 10: 169183.

CoDD, L.E.W. 1951. Bome en struike van die Nasionale Krugerwildtuin. Memoirs of the botanical Survey of South Africa 26: 1-192.

Coetzee, B.J. 1983. Phytosociology, vegetation structure and landscapes of the Central District, Kruger National Park, South Africa. Dissertations Botanicae. FL-9490 Vaduz, Germany.

EDWARDS, D. 1983. A broad scale structural classification of vegetation for practical purposes. Bothalia 14: 705-712.

FARRELL, J.A.K. 1968. Preliminary notes on the vegetation of the lower Sabi-Lundi basin, Rhodesia. Kirkia 6(3): 223-248.

Gabriel, H.W. \& S.S. TAlbot. 1984. Glossary of landscape and vegetation ecology for Alaska. BLM-Alaska Technical Report 10. U.S. Department of the Interior.

GAUCH, H.G. 1982. Multivariate analysis in community ecology. Cambridge: University Press.

GeERLING, C. 1982. Guide de terrain des ligneux Sahéliens et Soudano-Guinéens. Wageningen: Veenman

GertenBACH, W.P.D. 1983. Landscapes of the Kruger National Park. Koedoe 26: 9-121.

GILL, A.M. \& M.A. MCCARTHY. 1998. Intervals between prescribed fires in Australia: what intrinsic variation should apply? Biological Conservation 85: 161-169.

Golding, J.S. (ed.). 2002. Southern African Plant Red Data Lists. Pretoria: SABONET. (SABONET Report Series; no. 14.)

Grossman, D. \& P. HoldEN. 2002. Parque Nacional Do Limpopo, Management and Development Plan. Unpublished report to the Peace Parks Foundation.

HILl, M.O. 1979. TWINSPAN-A FORTRAN Program for Arranging Multivariate Data in an Ordered Two-way Table by Classification of the Individuals and Attributes. Ithaca, New York: Cornell University.

Hilton-TAYLOR, C. (compiler) 2000. 2000 IUCN Red List of Threatened Species. Gland, Switzerland: IUCN. (Downloaded on 30 August 2002.)

JONGMAN, R.H.G., C.F.J. TER BRAAK \& O.F.R. VAN Tongeren. 1987. Data analysis in community and landscape ecology. Wageningen: Pudoc.

KeLLY, R.D. \& B.H. WALKER. 1976. The effect of different forms of land use on the ecology of a semi-arid region in South-eastern Rhodesia. Journal of Ecology 64: 553-576.

Low, A.B. \& A.G. ReBelo. (eds.) 1996. Vegetation of South Africa, Lesotho and Swaziland. Pretoria: Department of Environmental Affairs and Tourism.

Mueller Dombois, D. \& H. Ellenberg. 1974. Aims and methods of vegetation ecology. New York, NY: John Wiley.

Muldavin, E.H., P. Neville \& G. Harper. 2001. Indices of grassland biodiversity in the Chihuahuan Desert Ecoregion derived from remote sensing. Conservation Biology 15(4): 844-855.

NATIONAL WORKING GROUP For VegetaTion ECOLOGY. 1986. Soil classification according to the binomial classification system. Pretoria: Botanical Research Institute. (Technical Communication 3.)

Scholes, R.J. \& B.H. Walker. 1993. An African savanna. Cambridge: Cambridge University Press.

Siebert, F., G.J. BredenKamp \& S.J. Siebert. 2003. A comparison of Mopaneveld vegetation in South Africa, Namibia and Zimbabwe. Bothalia 33(1): 121-134.

Stalmans, M. 1994. Vegetation survey of Malilangwe. Unpublished report to the Malilangwe Conservation Trust.

Ter BraAK, C.J.F. 1986. Canonical correspondence analysis: a new eigenvector technique for multivariate direct gradient analysis. Ecology 67(5): 1167-1179.

TER BRAaK, C.J.F. 1992. CANOCO-a FORTRAN program for canonical community ordination. Ithaca, New York: Microcomputor Power.

Timberlake, J.R., N. Nobanda \& I. Mapaure. 1993. Vegetation survey of the communal lands- 
north and west Zimbabwe. Kirkia 14(2): 171270.

VAn Der SchiJfF, H.P. 1957. Ekologiese studie van die flora van die Nasionale Krugerwildtuin. Deel 1. D.Sc. thesis. Univ. of Potchefstroom for CHE. Potchefstroom.

Van Rooyen N., G.K. Theron \& N. Grobbelaar. 1981a. A floristic description and structural classification of the plant communities of the Punda Maria-Pafuri-Wambiya area in the Kruger National Park, Rep. of S.A.: 1. The hygrophilous communities. Journal of South African Botany 47(2): 213-246.

Van Rooyen, N., G.K. Theron \& N. Grobbelaar. 1981b. A floristic description and structural analysis of the plant communities of the Punda Milia-Pafuri-Wambiya area in the Kruger National Park, Republic of South Africa: 2. The sandveld communities. Journal of South African Botany 47(3): 405-449.

VAn Rooyen, N., G.K. Theron \& N. GrobbelaAr. 1981c. A floristic description and structural classification of the plant communities of the Punda
Milia-Pafuri-Wambiya area in the Kruger National Park, Republic of South Africa: 3. The Colophospermum mopane communities. Journal of South African Botany 47(4): 585-626.

VAN WYK, P. 1973. Bome van die Nasionale Krugerwildtuin. Deel I en II. Johannesburg: Perskor.

VENTER, F.J. 1986. Soil patterns associated with the major geological units of the Kruger National Park. Koedoe 29: 125-138.

VENTER, F.J. \& W.P.D. GERTENBACH. 1986. A cursory review of the climate and vegetation of the Kruger National Park. Koedoe 29: 139-148.

VenteR, F.J. 1990. A classification of land for management planning in the Kruger National Park. Ph.D. thesis, University of South Africa, Pretoria.

Werger, M.J.A. \& B.J. Coetzee. 1978. The Sudano-Zambezian Region. Pp. 301-462. In: WERGER M.J.A. (ed.). Biogeography and ecology of southern Africa. The Hague: Dr W. Junk.

WiLD, H. \& L.A.G. BARBosA. 1967. Vegetation map of the Flora Zambesiaca Area. Salisbury, Rhodesia: Collins 